\section{David J.A. Clines}

University of Sheffield, Wielka Brytania

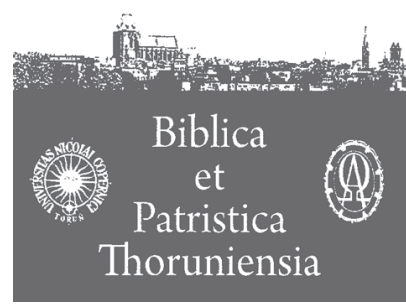

6 (2013) ISSN 1689-5150

\title{
Seven Interesting Things about the Epilogue to Job
}

\section{Siedem ciekawych rzeczy o epilogu Księgi Hioba}

Key words: the Book of Job; the Epilogue; the fortunes of Job; the wrath of Jahwe; intercessory prayer; "false naivety".

Słowa klucze: Księga Hioba; Epilog; powodzenie Hioba; los Hioba; gniew Jahwe; modlitwa wstawiennicza; „fałszywa naiwność”.

Abstract. In this paper I will draw attention to seven points in Job 42:7-17 that are not usually noticed or satisfactorily explained. (1) In what way has Job spoken of Yhwh what is right? (2) Does Job know of Yhwh's evaluation of him? (3) Why is Yhwh at risk of behaving outrageously? (4) Why should Job's prayer here be efficacious when his prayer in chap. 1 was not? (5) When are Job's fortunes restored? (6) What does the doubling of Job's possessions signify? (7) Why does Job live 140 years after his dispute with Yhwh? The Epilogue will be shown to be more subtle than is generally recognized, and the writing may be another example of the "false naivety" I have argued for previously in the Prologue.

Streszczenie. Autor skupia się na siedmiu kwestiach dotyczących Hi 42,7-17, które z reguły uchodzą uwadze komentatorów lub nie doczekały się satysfakcjonującego wyjaśnienia. (1) W jakim sensie Hiob mówił prawdy o Jahwe? (2) Czy Hiob wie o tym, jak go Jahwe ocenił? (3) Dlaczego Jahwe jest bliski wściekłości? (4) Dlaczego modlitwa Hioba jest tu skuteczna, skoro jego modlitwa w rozdziale 1 nie była taką? (5) Kiedy zostało przywrócone powodzenie Hiobowi? (6) Co oznacza podwojenie majątku Hioba? (7) Dlaczego Hiob żyje jeszcze 140 lat po swojej dyspucie z Jahwe? Clines pokazuje, że Epilog jest kolejnym przykładem „fałszywej naiwności”, którą widział także w Prologu.

The epilogue to the Book of Job has often been a source of discomfort to 1 its readers. Sometimes the "happy" ending of the Book has been thought an unfortunately shallow conclusion to the weighty theological debates of the dialogues. And sometimes the discomfort has been transmuted into a literary-critical judgment that the epilogue is a secondary addition to the original Book of Job. 
The result of this discomfort has been that the epilogue has not been given the same quality of exegetical attention as the former chapters of the book, ${ }^{1}$ and the subtlety of the narrative has been overlooked. ${ }^{2}$ In this paper I will draw attention to seven points in Job 42:7-17 that are not usually noticed or satisfactorily explained. I will frame the points as questions that quizzical readers may ask themselves.

\section{In What Way Has Job Spoken of Yhwh What Is Right?}

The first unexpected element in the epilogue is the sentence of Yhwh to the friends that they "have not spoken about me what is right, as my servant Job did" (v. 7, and again in v. 8). The term commonly translated "what is right" is hnkn which, as the niphal participle of juk "establish," should mean more precisely "what is established." It is hard to see what "established" could mean in the present context, and we probably have to be content with the translation "right, true," as do the standard English versions: "what is right" (RSv, NIV), "truthfully" (лв), "correctly" (Nјв), "truth" (NJPs); so too the Septuagint's a) hqei . Elsewhere hrkenor jkenapparently means "the truth" (Psa. 5:10 [ET 9); Deut. 13:15 [ET 14]), or "what is proper" (Exod. 8:26).

The question is: How can what Job has spoken about Yhwh be called "right"? Much of what Job has spoken about Yhwh has been abuse and criticism of the deity, and Yhwh himself has typified Job’s speeches as "darkening" (קvj hiph.) Yhwh's "design" ( $h x[$ ), that is, his principles for the structure of the universe, and has criticized Job for speaking "words without knowledge" (t [ dAll b y m) (38:2). Carol Newsom, for one, speaks of the "impossibility of harmonizing v. 7 with the preceding material in chaps. $3: 1-42: 6 .^{3}$

1 But see most recently Kenneth Numfor Ngwa, The Hermeneutics of the "Happy" Ending in Job 42:7-17 (BZAW, 254; Berlin: Walter de Gruyter, 2005); Dariusz Iwański, The Dynamics of Job's Intercession (AnBib, 161; Rome: Pontifical Biblical Institute, 2006).

2 The points dealt with in this article are raised in my commentary (Job 38-42 [Word Biblical Commentary, 18B; Nashville, TN: Thomas Nelson, 2011] 1225-42), but in passing, and accompanied by much other material. Here I focus systematically on what I call "interesting things," by which I mean elements that have been ignored by the majority of commentators. Inevitably therefore I can offer few references to the work of others. But see also most recently.

3 Carol Newsom, "The Book of Job. Introduction, Commentary, and Reflections," in The New Interpreter's Bible (ed. Leander Earl Keck; Nashville: Abingdon Press, 1996), IV, 317-637 (634). 
Yhwh, we must accept, cannot be referring to Job's initial speech of acceptance after his calamities have fallen upon him: "Yhwh has given and Yhwh has taken. May Yhwh's name be blessed" (1:21). For the deity plainly knows about the friends' speeches ("you have not spoken the truth about me," v. 7), and therefore must be aware of Job's own hostile speeches also, which rather cancel out Job's docile first speech. Nor is Yhwh likely to be referring to Job's short responses in 40:4-5 and 42:2-6, since they are surely too insubstantial to outweigh the criticisms Job has earlier made of Yhwh.

The only thing about Job's speeches that Yhwh can be approving of is Job's denial that Yhwh governs the world on a principle of retributive justice. For Job, it was a criticism of Yhwh that he did not keep days of assize, judgment days when he would mete out punishment to wrongdoers (24:1). For Yhwh, the whole of his speeches from the tempest (chaps. 38-41) implicitly deny that retribution for good or bad behaviour is a feature of the design of the world order. Yhwh's own depiction of his purpose for the universe emphasizes sustenance of its life forms, the non-human creation being a very prominent part of his concerns, rather than a micro-management of human beings. Job's complaints about God's failure to manage the universe have paradoxically put their finger upon a fundamental truth about Yhwh, that such is not his interest.

It is a remarkable, if not also shocking and even amusing, outcome to the Book of Job that its two protagonists, Job and Yhwh, who have appeared throughout to be enemies to each other, turn out to be on the same side on this fundamental issue. Job stands under reproach for not appreciating the scope of Yhwh's intentions for the universe, but he earns divine approbation for discerning that Yhwh does not indeed rule the world according to the dictates of retributive justice.

\section{Does Job Know of Yhwh's Evaluation of Him?}

Considering that Job is praised as the one person who has told the truth about Yhwh, and that Yhwh calls him "my servant" (v. 7), it is remarkable that Yhwh never discloses to him directly what he thinks of him. He can devote four chapters to his plans for the universe, including one in rapt admiration for the crocodile, but cannot spare Job a single line to put him out of his misery and tell him how he really regards him. It is not that Yhwh in this book will only deliver grand speeches: he can easily devote a couple of verses to the rather minor matter of how the friends may manage to escape divine wrath (vv. 7-8). It is truly strange that he doesn't have a single word for Job. 
If Yhwh never tells Job his opinion of him, does Job ever get to know about it? The narrative is only implicit. The friends have to go to Job and ask him to pray for them when they offer a sacrifice (v. 8). We may well wonder what they must say to Job. Can they make such a request of him without telling him what Yhwh has said to them? Perhaps they can, though it would be unimaginable cruelty to keep the amazing news from him. We probably have to assume that the friends report to Job what Yhwh really thinks about him.

If they don't, why would they be making a sacrifice? It looks like an atonement, but what does Job suppose their sin must be? And why, Job must ask himself, are they offering such an enormous sacrifice? Seven bulls and seven rams are all that have to offered for the whole people of Israel on the days of Passover according to Ezekiel's cultic calendar (Ezek. 45:23). In the three other cases in the Hebrew Bible where seven bulls and seven rams are offered (by Balaam, Num. 23:1, 29; at the installation of the ark of the covenant, 1 Chron. 15:26; at the cleansing of the temple, 2 Chron. 29:21), much bigger issues are involved than anything that has transpired in the rather academic atmosphere of the Joban dialogues.

The friends can hardly claim their sacrifice is a whim of their own; they must confess that it is required by Yhwh. But they can hardly tell Job that without also telling him why Yhwh is demanding it. They are surely obliged to report that Yhwh has taken up his cudgels against them, and even, perhaps, that he has taken Job's side rather than theirs. Even if they do not at first report to Job what Yhwh has said about him, the fact that they have to offer a penitential sacrifice whereas Job does not must be a broad hint to Job that he is more favoured than they are.

Nevertheless, whatever we may infer that Job has deduced from the friends' request, the narrative never actually tells us that Job discovers what Yhwh's evaluation of him is. It is equally obscure how and when Job will ever find out that his fortunes are being restored (see Section 5 below).

\section{Why Is Yhwh at Risk of Behaving Outrageously?}

In v. 8 there is a phrase that is almost universally mistranslated. Yhwh demands of the friends that they ask Job to pray for them, for he will accept Job ${ }^{4}$

4 The Hebrew aca ypAAa $\mathbf{k}$ makes little sense, for neither a literal translation "for if" nor the sense "but rather, except" for the compound preposition $\mu \mathrm{a}$ yk will fit. A small emendation of $\mu$ a to the object marker ta seems almost mandatory; it allows the intelligible translation "for I will accept his face". 
$\mathrm{hl}$ bn $\mu \mathrm{knh}$ tve[ $\Varangle \mathrm{ll} \mathrm{bl}$. This is commonly translated in English versions as "lest I deal with you after your folly" (KJV), or "not to deal with you according to your folly" (RSV, NRSV, NIV). Such a translation is without justification, since there is nothing in the Hebrew corresponding to "according to" or "after," and "folly" is certainly an inappropriate translation of $\mathrm{hl}$ bn. It would better be translated "so as not to deal outrageously with you," "so that I do not commit an outrage upon you."

hl bnhas been defined by Wolfgang M.W. Roth as "a sacrilegious act," 6 that is, a breaking of religio-social rules of conduct, and by Anthony Phillips as socially disruptive behaviour.7 The phrase $\mathrm{hl}$ bnhc[ "commit sacrilege" or "engage in disorderly conduct" occurs in Gen. 34:7; Deut. 22:21; Josh. 7:15; Judg. 19:23; 20:6, 10; 2 Sam. 13:12; and Jer. 29:23. It is a term from the world of social relations; it is not to do with the world of mental processes and abilities, as the common translation "folly" suggests.

The important point here is that the $\mathrm{hl}$ bnis not behaviour attributed to the friends, but behaviour that Yhwh says he may engage in if he is not appeased by Job's prayer. It is the outrageous behaviour of a person whose anger is out of control. It is noteworthy that v. 7 has said that Yhwh's anger ( $\varpi a)$ has burned hot (hrj) against Eliphaz and the other friends. This is the only place in the book where Yhwh is said to be angry. Though Job has inferred Yhwh's anger from his experience of him $(14: 13 ; 16: 9 ; 19: 11)$, the only time we have seen anger is when Elihu becomes angry with impatience at the inability to refute Job adequately $(32: 2,3,5)$. Yhwh is angry here for the first and only time.

The anger of Yhwh, his demand for an enormous sacrifice, and his threat of outrageous behaviour all cohere. We are meant to sense that the friends' imposition of the principle of retributive justice upon Yhwh's dealings with the world is regarded by him as a terrible affront, and a tragic misunderstanding about the divine design for the world. If Job has been "darkening" the design (42:3), they have been doing worse: their arguments seem to have been bent on destroying it.

In an unguarded moment, Yhwh lets slip that he feels in danger of behaving badly, outrageously in fact, but he knows how he can bring himself under

5 The translations of nab "not to punish you severely," njps "not treat you vilely," neb "by not being harsh with you," njb "shall not inflict my displeasure on you," and gnb "not disgrace you the way you deserve" also miss the point that Yhwh is speaking of improper behaviour on his part.

6 Roth, “Nbl,” VT 10 (1960) 394-409.

7 Phillips, "Nebalah - A Term for Serious Disorderly and Unruly Conduct," VT 25 (1975) 237-42. 
control: a pious person can intercede with him on behalf of those who have aroused his anger. Then he will calm down.

\section{Why Should Job's Prayer Here Be Efficacious When his Prayer in Chap. 1 Was Not?}

From Job's point of view, there can be little expectation that his prayer will be heard. In chap. 1, his offerings on behalf of his children, whenever they had held a birthday party, were notably unsuccessful. His prayers did not prevent their deaths, which are recounted in climactic position in the reports of the three messengers (1:18-19).

We do not know for sure, in the present context, what the friends have told Job about the background to his prayer that they are asking him to make. Does he know that Yhwh has demanded it? Does he know that Yhwh has undertaken in advance to "accept" him when he prays it?

We must remember that Job has not yet been restored when the friends bring their request to him for his prayer. He is presumably still on the ashheap. He has no inkling that Yhwh intends to reverse his fortunes. All he knows is that he is still suffering at Yhwh's hand, and, if it is difficult for the friends to acknowledge the divine judgment against them, it must be no less difficult for Job to accept this second-hand instruction to offer prayer for people he must be totally disenchanted with; he certainly owes them nothing. If he prays for them, is he reconciled with them, or does he just do what Yhwh has bid him do, out of his inexhaustible piety?

It may be some consolation to Job to know in advance, this time, that his prayer will be answered. Maybe he would rather that it should not be answered, and that Yhwh should do something rash with the friends, as he is tempted to do. Is this yet another "test" that Job must undergo before he is restored?

\section{When Are Job's Fortunes Restored?}

This is another point that is rarely if ever considered by commentators. There are two issues here: a matter of correctly understanding the Hebrew, and a matter of the narrative logic.

The Hebrew says that Yhwh restored the fortunes of Job va[ $r \mathrm{~d}[\mathrm{~b} w \mathrm{w}$ pthb (v. 10). which one would think ought to mean "while he was praying for his friends." The preposition beth prefixed to an infinitive construct usually means

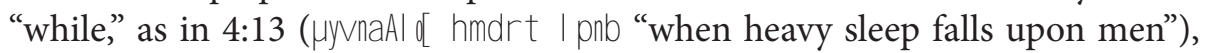


6:17 ( $\mu$ anmmk[ dnumib "when it is hot, they [streams] vanish from their place"), and 29:3 (yvar y [ wn whb "when his lamp shone over my head"). Only one of the standard modern English translations of the Bible, however, understands the Hebrew in this way: the New Jerusalem Bible with its translation "And Yhwh restored Job's condition, while Job was interceding." RSV, NRSV, NJPS, on the other hand, have "when he had prayed" and NIV, NAB "after Job had prayed," obviously finding it hard to understand why Job's restoration should have taken place during his prayer. But such translations are hard to justify from the Hebrew.

The point about the narrative logic is the issue of when exactly we are to envisage Job's fortunes being restored. Leaving aside the question whether the Hebrew tyovA a bw really does mean "restore the fortunes," ${ }^{8}$ we must consider what it would mean for his fortunes to be restored. In the context of the narrative of the epilogue, it must be Job's acquisition of new flocks and new children, as it is described in vv. 12-13: "Job had fourteen thousand sheep, six thousand camels, a thousand yoke of oxen and a thousand she-asses. He also had seven sons and three daughters." Now this access of new wealth and a new family cannot be imagined as happening in an instant, for the Book of Job is a folk tale, not a fairy tale (in which miraculous events may occur). Presumably his enormous flocks are built up over the course of time and through natural processes; the favour of Yhwh will have made them especially fecund, but there will have been nothing miraculous about the appearance of these vast herds of livestock on his grazing lands. And, at the moment when he is praying for his friends, he has still ten children to be born to him. So the restoration of his fortunes must lie at least ten years in the future (he still has only one wife, as far as we know). In fact, the numbers of his flocks in vv. 12-13 must be what he possesses at the end of his life; for if they had reached such figures earlier, they would have been higher still by the time of his death-which would mean that Yhwh would have ultimately given him much more than twice as much as he had at the beginning of the book.

What this line of reasoning goes to show is that at the moment of Job's praying for his friends, nothing has changed in the visible external world. His for-

8 It is strange that the verb bw qal, which normally means "return," has an object here, and strange that the noun $t W_{2}$ ] which normally means "captivity," apparently means "restoration" here. But there are other examples of bw qal with an object (see David J.A. Clines, The Dictionary of Classical Hebrew, VIII: Sin-Taw [Sheffield: Sheffield Phoenix Press, 2011] $287)$, and is at least arguable that t vov "restoration" is a different word from t "captivity" (DCH, 8: 229a). For an overview, see J.M. Bracke, “šûb šébût: A Reappraisal," ZAW 97 (1985) 233-44. 
tunes may have been restored in Yhwh's eyes, or in Yhwh's intentions, but no one can know that, least of all Job himself.

Now readers generally do not read slowly enough to appreciate this aspect of the narrative. They get the impression that Job's restoration is instantaneous and that it is evident. They are hurried on by the narrative to the next scene, in which all his family and acquaintances gather to visit him and bring him tokens to welcome him back into normal life. But readers are misled if they suppose that Job's visitors have witnessed the sudden restoration of all his property and so have decided it is worth associating with him again. They know nothing about any restoration. They only know that Job has decided to bring his period of mourning to an end, and to accept consolation (as $\mu \mathrm{j}$ nin v. 7 properly means). ${ }^{9}$ For that reason, they do not come to rejoice with him that his wealth has been restored, but to "grieve" with him (dv) and to "console" ( $\mu$ j in him (v. 11) - to grieve with him since he will always have lost what he has lost, and to console him because he is now open to the future. ${ }^{10}$

So, if nothing observable happens at the moment Yhwh restores the fortunes of Job there is no impediment to understanding the restoration as essentially occurring in the mind of Yhwh. Though it will issue in Yhwh "blessing" Job over the course of the rest of his life (v. 12), it would seem that the "restoration" is more closely connected with Job's prayer than is usually recognized.

What is it about Job's prayer that changes the disposition of the deity? We have noticed above that the purpose of Job's prayer is to prevent Yhwh from acting outrageously ( $\mathrm{hl}$ bnhc[ ). Job saves Yhwh from himself, and does so precisely by his prayer. Yhwh is, understandably, grateful. It is for this reason that the text says that Yhwh restored the fortunes of Job while he was praying for his friends. It is not because he is praying, nor because he is praying for his friends, but because he is reducing the level of Yhwh's anger, and preventing Yhwh from disgracing himself.

9 See further my Job III, 1208-1209, 1221.

10 P.A.H. de Boer puts it well when he says: "[T] o consider the period of mourning as closed is not the same as being compensated for it or denying the loss one has suffered: it means to live on, to turn a new page in the book of one's life" " Does Job Retract? Job xlii 6," in his Selected Studies in Old Testament Exegesis [ed. C. van Duin; OTS 27; Leiden: E.J. Brill, 1991] 179-95 [192]). 


\section{What Does the Doubling of Job's Possessions Signify?}

Readers of v. 12 need to have a good memory. In 1:3 they were told that before his affliction Job had 7000 sheep, 3000 camels, 500 yoke of oxen and 500 donkeys. Here they find that the number of each of his flocks after his restoration is exactly double that. A "restoration" would surely be of animals to the same number, but this (though the text does not say so explicitly) is a doubling.

Though almost no commentators notice it, by giving Job double what he had lost, Yhwh is paying him compensation. It appears that allusion is being made to the law of Exod. 22:3 (ET 4), where a thief is required to pay double compensation for the theft of an animal, "whether ox or donkey or sheep." Francis I. Andersen rightly makes the connection, writing: "It is a wry touch that the Lord, like any thief who has been found out (Exod 22:4), repays Job double what he took from him."11

But if the significance of the doubling of Job's possessions is here rightly understood, it is far more than a "wry touch"; it is critical for the narrative of the book. For it was Job's fundamental complaint-that he had been unjustly treated in being deprived of his possessions and his good name-that spurred the whole argument of the book. It has been an ethical problem for readers also, who, even if they have not been enmeshed in the doctrine of retribution as it was taught in Job's world, have not been able to accept the initial act of Yhwh's seizure of Job's possessions as justifiable. ${ }^{12}$ Yhwh, we note, says nothing about the injustice of his theft of Job's possessions and his honour, or that he is attempting to compensate for it, and the narrative gives no explicit hint of the huge significance of the doubling of Job's wealth. But it makes a difference to our reading of the book as a whole if we know that at the end of the day the wrong done to Job in chap. 1 is righted-even if it is not stated in so many words, even if there is no apology, even though Job's dead children cannot be replaced by his new family. Though the narrator has just now reminded us (v. 11) that the harm Job suffered was indeed Yhwh's responsibility, Yhwh does not verbally acknowledge that a wrong was done to Job. But his doubling of Job's possessions says it all.

11 Even if there is not an intentional reference to the Exodus passage, restoring to Job more than has been taken from him would seem to be an admission of a wrong done to him.

12 See further my paper "Job's Fifth Friend: An Ethical Critique of the Book of Job", Biblical Interpretation 12 (2004) 233-50. 


\section{Why Does Job Live 140 Years after his Dispute with Yhwh?}

I have not found any commentator who thinks the number of 140 years is particularly significant. Yet in the light of the doubling of the number of Job's animals noted above, it seems inescapable that the 140 years is also to be understood as a doubling. We recall that, according to Ps 90:10, 70 years is regarded as the normal life span. If Job lives for 140 years after his trials, it can only mean that his life-span has been started again from scratch. His former life is thus effectively cancelled, and he will live as if those days had not been. It is not that he has necessarily already actually lived 70 years, but that the clock of his days has been restarted, except that his allotment has become twice the normal 70 .

This may not be a genuine "restoration," for it sweeps under the carpet all the years of his former life, just as it does also his first family and his former servants and animals. But, given that they are not going to be resurrected, perhaps this is the best that can be done.

\section{Conclusion}

Quite some time ago, I wrote a paper entitled, "False Naivety in the Prologue to Job." ${ }^{13}$ I find that I have now written a paper on false naivety in the epilogue to Job, even though that theme was not my primary intention. In that earlier paper I remarked that "False naivety exploits the appearance of artlessness to convey a subtle message," and continued:

Subtle and complex as the argument of the book as a whole is, its naive prologue is no less subtle: it is not some primitive tale that does no more than set the scene for the substantive argument of the dialogues, but a well-wrought narrative that plunges directly into issues of substances that reach as deep as the fraught dialogues themselves. False naivety is not, let it be noted, an act of bad faith; it is a beguilement of the reader, a strategy that, if it seduces naive readers into finding a reflection of their own shallowness in the text, equally entrances more perceptive readers into an exploratory journey into its depths. It produces an open text and a closed text at the same time.

13 Hebrew Annual Review 9 (1985) 127-36 (= Biblical and Other Studies in Memory of Shelomo Dov Goitein [ed. Reuben Ahroni]); reprinted in my On the Way to the Postmodern: Old Testament Essays, 1967-1998, vol. 2 (Journal for the Study of the Old Testament Supplement Series, 293; Sheffield: Sheffield Academic Press, 1998) 735-44. 
Mutatis mutandis, I think the same may be said about the epilogue. I would characterize these elements of the epilogue as examples of false naivety:

1. The excessive anger of Yhwh against the friends, to the extent of his considering committing an "outrage" against them (v. 7).

2. The excessive size of the offering required from the friends (v. 8).

3. The round numbers of seven bulls and seven rams (v. 8).

4. The restoration of Job at the moment he prays for his friends (v. 10).

5. The impression that Job's restoration happens in a instant (v. 10).

6. The restoration to Job of twice his former wealth (v. 12).

7. The "perfect" numbers of his seven sons and three daughters (v. 13).

I call the naivety "false" only because it masks, to some extent, the highly sophisticated content of the narrative. In fact, the epilogue to Job is among the most subtle and most thoughtful writing in the entire book, and deserves to be recognized as a fitting and indeed indispensable conclusion to the Book of Job. 